\title{
Influence of virgin coconut oil-enriched diet on the transcriptional regulation of fatty acid synthesis and oxidation in rats - a comparative study
}

\author{
Sakunthala Arunima and Thankappan Rajamohan* \\ Department of Biochemistry, University of Kerala, Thiruvananthapuram-695581, India \\ (Submitted 13 May 2013 - Final revision received 17 December 2013 - Accepted 19 December 2013 - First published online 11 February 2014)
}

\begin{abstract}
The present study was carried out to evaluate the effects of virgin coconut oil (VCO) compared with copra oil, olive oil and sunflower-seed oil on the synthesis and oxidation of fatty acids and the molecular regulation of fatty acid metabolism in normal rats. Male Sprague-Dawley rats were fed the test oils at $8 \%$ for $45 \mathrm{~d}$ along with a synthetic diet. Dietary supplementation of VCO decreased tissue lipid levels and reduced the activity of the enzymes involved in lipogenesis, namely acyl CoA carboxylase and fatty acid synthase (FAS) $(P<0 \cdot 05)$. Moreover, VCO significantly $(P<0.05)$ reduced the de novo synthesis of fatty acids by down-regulating the mRNA expression of FAS and its transcription factor, sterol regulatory element-binding protein-1c, compared with the other oils. VCO significantly $(P<0 \cdot 05)$ increased the mitochondrial and peroxisomal $\beta$-oxidation of fatty acids, which was evident from the increased activities of carnitine palmitoyl transferase I, acyl CoA oxidase and the enzymes involved in mitochondrial $\beta$-oxidation; this was accomplished by up-regulating the mRNA expression of PPAR $\alpha$ and its target genes involved in fatty acid oxidation. In conclusion, the present results confirmed that supplementation of VCO has beneficial effects on lipid parameters by reducing lipogenesis and enhancing the rate of fatty acid catabolism; this effect was mediated at least in part via PPAR $\alpha$-dependent pathways. Thus, dietary VCO reduces the risk for CHD by beneficially modulating the synthesis and degradation of fatty acids.
\end{abstract}

Key words: Virgin coconut oil: Fatty acid synthesis: $\beta$-Oxidation: PPAR $\alpha$

CVD, which is often associated with hyperlipidaemia, has become the major cause of death in many countries ${ }^{(1,2)}$. Elevated peripheral NEFA and de novo lipogenesis predominantly contribute to the accumulation of lipids in the liver ${ }^{(3)}$, which is mostly controlled by the intake of different dietary fats through changes in hepatic enzyme activities related to the metabolism of fatty acids ${ }^{(4)}$. In general, fat accumulation in the body may be considered as the net result of the balance among dietary absorbed fat, endogenous synthesis of fat and the catabolism of fat via $\beta$-oxidation.

It has been shown that different fatty acids exert different effects on the transcription of specific genes involved in hepatic lipid metabolism ${ }^{(5,6)}$. Transcriptional regulation of fatty acid metabolism is considered to be the major regulatory mechanism controlling lipid homeostasis, which is executed by a variety of transcription factors ${ }^{(7)}$. Sterol response element-binding protein-1c (SREBP-1c; $68 \mathrm{kDa}$ ) is a transcription factor known to be the major regulator of lipogenic enzymes ${ }^{(8)}$ and reduced expression of SREBP-1c is a primary mechanism by which dietary fatty acids reduce hepatic lipogenesis. In contrast with the numerous factors involved in fatty acid synthesis and storage, the transcriptional regulation of fatty acid oxidation has long been dominated by $\operatorname{PPAR} \alpha$, which is a nuclear receptor activated by natural ligands such as fatty acids and stimulates $\beta$-oxidation of SFA in mitochondria and PUFA in the peroxisomes ${ }^{(9)}$. Some of the enzymes of these two systems are highly inducible by natural and synthetic ligands of PPAR $\alpha^{(10,11)}$.

Nutritional status, particularly the dietary fatty acid pattern of the individual, plays a key role in regulating fatty acid metabolism $^{(12)}$. The diversity in fatty acid structure resulting from differences in chain length, degree of unsaturation, position and stereoisomeric configuration of the double bonds may affect the rate of fatty acid oxidation. Although the usual dietary fats composed of mainly long-chain fatty acids are known to be powerful inhibitors of lipogenesis in the liver and adipose tissue ${ }^{(13)}$, paradoxically they produce obesity ${ }^{(14)}$.

Coconut oil extracted from dried copra is the characteristic cooking medium in most of the culinary preparations in all coconut-producing countries. Nowadays, virgin coconut oil (VCO) extracted from fresh coconut kernel by wet processing is

Abbreviations: ACC, acetyl CoA carboxylase; ACDH, acyl CoA dehydrogenase; ACO, acyl CoA oxidase; CO, copra oil; CPT I, carnitine palmitoyl transferase I; FAS, fatty acid synthase; MSE, mannitol-sucrose-EDTA; OO, olive oil; SFO, sunflower-seed oil; SIRT1, sirtuin 1; SREBP-1c, sterol regulatory elementbinding protein-1c; VCO, virgin coconut oil.

*Corresponding author: Professor T. Rajamohan, fax +91 471 2308078, email trmohanbio@gmail.com 
becoming very valuable because of its biological properties. Individual fatty acid analysis of the two types of coconut oil has revealed the presence of higher amounts of short- and medium-chain TAG, mainly lauric acid ${ }^{(15)}$. The major advantage of medium-chain fatty acids in coconut oil is that they are more rapidly oxidised by both mitochondrial and peroxisomal pathways compared with MUFA and PUFA ${ }^{(16)}$. Moreover, VCO extraction by wet processing retains higher amounts of unsaponifiable components such as polyphenols, tocopherols and phytosterols ${ }^{(17,18)}$. Previous studies have reported that VCO possesses significant hypolipidaemic, antioxidant and antithrombotic effects compared with copra oil $(\mathrm{CO})^{(15,17,19)}$. In addition, our recent reports have revealed that VCO has beneficial effects on regulating hepatic lipid metabolism in vivo ${ }^{(20)}$.

In view of these findings, the present study was carried out to evaluate the effects of VCO compared with $\mathrm{CO}$, oleate-rich olive oil (OO) and linoleate-rich sunflower-seed oil (SFO) on the synthesis and oxidation of fatty acids and its effect on the transcriptional regulation of fatty acid metabolism in rats.

\section{Materials and methods}

\section{Chemicals}

Acetyl CoA, malonyl CoA, NAD phosphate, L-carnitine, ATP, TRI reagent and primers used for RT-PCR were obtained from Sigma Chemicals. cDNA synthesis and PCR reactions were performed using a kit purchased from Fermentas, Thermo Fisher Scientific Inc. and all other chemicals used were of the highest analytical grade.

\section{Extraction of virgin coconut oil and copra oil}

The solid endosperm of mature coconut (West coast tall variety) was crushed, made into viscous slurry and squeezed through cheesecloth to obtain coconut milk, which was refrigerated for $48 \mathrm{~h}$, then subjected to mild heating $\left(50^{\circ} \mathrm{C}\right)$ in a thermostat oven. The obtained VCO filtered through cheesecloth was used for the present study ${ }^{(17)}$. CO was extracted from coconut meat, which was dried in sunlight continuously for $4 \mathrm{~d}$ to remove moisture and the resulting copra was pressed in a mill to obtain $\mathrm{CO}^{(17)}$

\section{Olive oil and sunflower-seed oil}

OO (Pietro Coricelli brand) and SFO (Sun drop brand) were purchased from a local market.

\section{Animals}

Male Sprague-Dawley rats (100-120 g) bred in our departmental animal house were used for the study. Animals were individually housed under hygienic conditions in polypropylene cages in a room maintained at an ambient temperature of $25 \pm 1^{\circ} \mathrm{C}$ with a $12 \mathrm{~h}$ light $-12 \mathrm{~h}$ dark cycle. The entire protocol was approved by the Animal Ethics Committee, University of Kerala (IAEC-KU-8/09-10-BC-TR [17]) and the animals were handled using welfare guidelines for laboratory animals.

\section{Experimental design}

A total of twenty-four rats were divided into four groups. The experimental design was as follows: group I rats were given $8 \% \mathrm{CO}$; group II rats were given $8 \% \mathrm{VCO}$; group III rats were given $8 \% \mathrm{OO}$; and group IV rats were given $8 \% \mathrm{SFO}$. Each rat was given $12 \mathrm{~g}$ synthetic diet containing $8 \%$ dietary oils daily for $45 \mathrm{~d}$ as described previously (Table 1$)^{(17,21)}$ The fatty acid compositions of test oils were estimated by GC-MS and reported previously (Table 2$)^{(22)}$. Food intakes of rats were noted daily and the body weight was determined weekly. After $45 \mathrm{~d}$, animals were fasted overnight and killed by sodium pentathone injection. Blood and tissues were collected for various estimations.

\section{Change in body weight}

The body weight of each animal was noted before starting the feeding experiment and also on the experimental day. Change in body weight was calculated as follows:

$$
\text { Change in body weight }(\mathrm{g})=\text { final weight }- \text { initial weight. }
$$

\section{Lipid analysis}

Total lipids from serum and tissues were extracted using chloroform-methanol $(2: 1, \mathrm{v} / \mathrm{v})$ as described previously ${ }^{(23)}$. Tissue $(500 \mathrm{mg})$ or serum $(0.5 \mathrm{ml})$ was homogenised with chloroform-methanol $(2: 1, \mathrm{v} / \mathrm{v})$, filtered and washed with chloroform-methanol at least three times. Calcium chloride $(0.02 \%)$ was added to the mixture $(20 \%$ of the total volume of the extract), mixed vigorously and allowed to stand for a few minutes. The upper layer was washed three times with $5 \mathrm{ml}$ chloroform-methanol-calcium chloride (3:48:48, by vol.). The washed upper layer was evaporated to dryness and the residue was redissolved in a known volume of chloroform. From this, samples were used for lipid analysis. Total cholesterol was estimated as described by Carr \& Drekter ${ }^{(24)}$. TAG were estimated by the method of Van Handel \& Zilversmit ${ }^{(25)}$.

Table 1. Formulation of synthetic diet used for the study

\begin{tabular}{lcccc}
\hline Ingredients (\%) & Group I & Group II & Group III & Group IV \\
\hline Maize starch & 71 & 71 & 71 & 71 \\
Casein & 16 & 16 & 16 & 16 \\
Copra oil & 8 & - & - & - \\
Virgin coconut oil & - & 8 & - & - \\
Olive oil & - & - & 8 & - \\
Sunflower-seed oil & - & - & - & 8 \\
Salt mixture* & 4 & 4 & 4 & 4 \\
Vitamin mixture† & 1 & 1 & 1 & 1 \\
\hline
\end{tabular}

* Composition of salt mixture (per kg diet) ${ }^{(71)}: \mathrm{NaCl}, 105 \mathrm{mg} ; \mathrm{KCl}, 120 \mathrm{mg} ; \mathrm{KH}_{2} \mathrm{PO}_{4}$ $310 \mathrm{mg} ; \mathrm{Ca}_{4}\left(\mathrm{PO}_{4}\right)_{2}, 149 \mathrm{mg} ; \mathrm{CaCO}_{3}, 210 \mathrm{mg} ; \mathrm{MnSO}_{4}, 0.2 \mathrm{mg} ; \mathrm{KAI}\left(\mathrm{SO}_{4}\right)_{2}$, $0.09 \mathrm{mg} ; \mathrm{MgSO}_{4}, 90 \mathrm{mg} ; \mathrm{FeSO}_{4} \cdot 7 \mathrm{H}_{2} \mathrm{O}, 14.7 \mathrm{mg} ; \mathrm{CuSO}_{4}, 0.37 \mathrm{mg} ; \mathrm{NaF}, 0.57 \mathrm{mg}$ $\mathrm{KI}, 0.05 \mathrm{mg} ; \mathrm{ZnCl}_{2}, 0.02 \mathrm{mg} ; \mathrm{CoCl}_{2}, 0.15 \mathrm{mg}$.

† Composition of vitamin mixture (per $100 \mathrm{~g}$ diet): retinyl palmitate, $3 \mathrm{mg}$ ergocalciferol, $3.75 \mu \mathrm{g}$; $\alpha$-tocopherol, $12 \mathrm{mg}$; menadione, $0.3 \mathrm{mg}$; thiamine, $1 \mathrm{mg}$; riboflavin, $1 \mathrm{mg}$; pyridoxine, $0.6 \mathrm{mg}$; niacin, $10 \mathrm{mg}$; calcium pantothenate, $5 \mathrm{mg}$ inositol, $20 \mathrm{mg}$; folic acid, $0.4 \mathrm{mg}$; vitamin $\mathrm{B}_{12}, 3 \mu \mathrm{g}$; biotin, $20 \mu \mathrm{g}$; $p$-aminobenzoic acid, $5 \mathrm{mg}$; choline chloride, $300 \mathrm{mg}$. 
Table 2. Fatty acid composition of test oils in the diet

(Mean values of three estimations with their standard errors)

\begin{tabular}{|c|c|c|c|c|c|c|c|c|}
\hline \multirow[b]{2}{*}{ Fatty acid (\%) } & \multicolumn{2}{|c|}{ Copra oil } & \multicolumn{2}{|c|}{$\begin{array}{l}\text { Virgin coconut } \\
\text { oil }\end{array}$} & \multicolumn{2}{|c|}{ Olive oil } & \multicolumn{2}{|c|}{$\begin{array}{l}\text { Sunflower-seed } \\
\text { oil }\end{array}$} \\
\hline & Mean & SEM & Mean & SEM & Mean & SEM & Mean & SEM \\
\hline $6: 0$ & 0.68 & 0.02 & 0.80 & 0.03 & - & - & - & - \\
\hline $8: 0$ & $6 \cdot 7$ & 0.25 & 7.5 & 0.28 & - & - & - & - \\
\hline $10: 0$ & $7 \cdot 0$ & 0.27 & $7 \cdot 7$ & 0.34 & - & - & - & - \\
\hline $12: 0$ & $45 \cdot 4$ & 1.72 & 46.4 & 1.77 & - & - & - & - \\
\hline $14: 0$ & 17.5 & 0.67 & $16 \cdot 9$ & 0.64 & - & - & - & - \\
\hline $16: 0$ & 9.2 & 0.50 & 8.5 & 0.41 & 22.5 & 0.86 & $17 \cdot 0$ & 0.65 \\
\hline $16: 1$ & - & - & - & - & $2 \cdot 9$ & 0.11 & - & - \\
\hline $18: 0$ & 3.9 & 0.15 & 4.2 & 0.16 & $10 \cdot 1$ & 0.39 & 11.6 & 0.44 \\
\hline $18: 1$ & $7 \cdot 6$ & 0.28 & 6.6 & 0.26 & 62.3 & 2.37 & 20.9 & 0.65 \\
\hline $18: 2$ & $2 \cdot 1$ & 0.08 & 1.4 & 0.05 & - & - & $47 \cdot 1$ & 1.77 \\
\hline $18: 3$ & 0.15 & 0.01 & 0.21 & 0.01 & 0.67 & 0.03 & 0.45 & 0.02 \\
\hline $20: 0$ & - & - & - & - & $2 \cdot 2$ & 0.11 & 1.4 & 0.05 \\
\hline $22: 0$ & - & - & - & - & - & - & $2 \cdot 1$ & 0.08 \\
\hline
\end{tabular}

\section{Estimation of phospholipids}

Phospholipids were estimated by the method of Zilversmit \& Davis ${ }^{(26)}$. A sample of the extract was pipetted out into Kjeldahl flask and evaporated to dryness. Then $1 \mathrm{ml} \mathrm{H}_{2} \mathrm{SO}_{4}(2 \cdot 5 \mathrm{M})$ was added and the sample was digested until it became light brown. It was cooled to room temperature and two drops of $\mathrm{HNO}_{3}(2 \mathrm{M})$ were added and the sample digested again until it became colourless. The Kjeldahl flask was cooled, $1 \mathrm{ml}$ water was added and heated in a boiling water-bath for $5 \mathrm{~min}$. Then $1 \mathrm{ml}$ of ammonium molybdate (2.5\%) and $0.1 \mathrm{ml}$ of 1 -amino 2-naphthol 4-sulfonic acid (ANSA) reagent were added and the volume made up to $10 \mathrm{ml}$ with distilled water. After $10 \mathrm{~min}$, absorbance was measured at $660 \mathrm{~nm}$ using a Shimadzu 1240 spectrophotometer.

\section{Isolation of mitochondria and peroxisomes}

Mitochondria were separated from the heart according to Tyler \& Gonze ${ }^{(27)}$. Rat heart tissue was washed in cold MSE medium (0.225 M-mannitol, 0.075 M-sucrose and 0.05 mm-EDTA, pH 7.4) and finely chopped. The chopped heart tissue was washed continuously with MSE medium to remove adhering blood. The heart tissue was then homogenised in $5 \mathrm{ml}$ of MSE medium and $0.05 \mathrm{ml}$ of un-neutralised Tris buffer $(1 \mathrm{M})$. The homogenate was then diluted to $40 \mathrm{ml}$ with MSE medium, divided equally into two centrifuge tubes and centrifuged at $8000 \mathrm{~g}$ for $10 \mathrm{~min}$. The supernatant fraction was decanted and the whole pellet was re-suspended in $40 \mathrm{ml}$ of MSE medium. After a second centrifugation at $700 \boldsymbol{g}$ for $10 \mathrm{~min}$, the supernatant fraction was collected and the pellets were discarded. A third centrifugation at $8000 \mathrm{~g}$ for $10 \mathrm{~min}$ was done to obtain mitochondrial fractions and the supernatant fraction was discarded. The mitochondrial pellet was then re-suspended in the appropriate buffer as described for each enzyme estimation. The $700 \boldsymbol{g}$ peroxisomal fraction obtained during mitochondrial isolation was used for studying peroxisomal $\beta$-oxidation ${ }^{(28)}$. The protein contents in the subcellular fractions were determined by the method of Lowry et $a l .^{(29)}$.

\section{Mitochondrial and peroxisomal $\beta$-oxidation}

Mitochondrial $\beta$-oxidation ${ }^{(30)}$ and the activities of carnitine palmitoyl transferase I (CPT I $)^{(31)}$, acyl CoA dehydrogenase $(\mathrm{ACDH})^{(32)}$, enoyl CoA hydratase ${ }^{(33)}$, $\beta$-hydroxy acyl CoA dehydrogenase $^{(34)}$ and 3-ketoacyl CoA thiolase ${ }^{(35)}$ were determined in isolated mitochondria. The peroxisomal fraction was used for determining the activity of acyl CoA oxidase (ACO) ${ }^{(36)}$.

\section{De novo fatty acid synthesis}

The enzymes involved in de novo fatty acid synthesis, namely acetyl CoA carboxylase (ACC) ${ }^{(37)}$ and fatty acid synthase $(\text { FAS })^{(38)}$, were assayed in liver using a Shimadzu 1240 spectrophotometer.

\section{Isolation of total genomic RNA}

Total genomic RNA was isolated from the heart using TRI reagent (Sigma Aldrich) by the method described by Chomczynski \& Mackey $^{(39)}$.

\section{CDNA synthesis and RT-PCR}

cDNA synthesis and PCR reactions were performed in a thermocycler (Eppendorf AG) according to the manufacturer's instructions using a kit purchased from Fermentas. The primers used were: FAS (forward) 5'-AGG TGC TAG AGG CCC TGC TA-3' and (reverse) $5^{\prime}$-GTG CAC AGA CAC CTT CCC AT-3'; SREBP1c (forward) 5'-GGAGCCATGGATTGCACATT- $3^{\prime}$ and (reverse) 5'-AGGAAGGCTTCCAGAGAGGA-3'; CPT I (forward) 5'-GGA GAC AGA CAC CAT CCA ACA TA- $3^{\prime}$ and (reverse) $5^{\prime}$-AGG TGA TGG ACT TGT CAA ACC-3'; ACO (forward) 5'-CTT TCT TGC TTG CCT TCC TTC TCC- $3^{\prime}$ and (reverse) 5'-GCC GTT TCA CCG CCT CGT A- $3^{\prime}$; PPAR $\alpha$ (forward) 5'-TCACACAATGCAATCCGTTT- $3^{\prime}$ and (reverse) $5^{\prime}$-GGCCTTGACCTTGTTCATGT-3'; glyceraldehyde-3-phosphate dehydrogenase (GAPDH) (forward) 5'-CCT TCA TTG ACC TCA ACT AC-3' and (reverse) 5'-GGA AGG CCA TGC CAG TGA GC-3'. 
The PCR products were electrophoresed on $1.5 \%$ agarose gel and visualised by staining with ethidium bromide. The gels were subjected to densitometric scanning (Bio-Rad Gel Doc) to determine the optical density of each and then normalised against an internal control (GAPDH) using Quantity One imaging software (Bio-Rad Laboratories).

\section{Statistical analysis}

Data are presented as means with their standard errors. Statistical analysis was performed by one-way ANOVA followed by Duncan's multiple-range tests using the SPSS/PC (version 17.0; SPSS) software package program. $P$ values $<0.05$ were considered significant.

\section{Results \\ Dietary intake and change in body weight}

There was no significant difference in diet consumption and change in body weight among the experimental groups (Table 3).

\section{Effect on serum and liver lipids}

Table 4 summarises the levels of lipids in the serum and liver of rats fed the different test oils. The concentration of total cholesterol $(1.87 \mathrm{mmol} / \mathrm{l}$ serum; $128.57 \mathrm{mg} / 100 \mathrm{~g}$ liver $)$, TAG $(0.11 \mathrm{mmol} / 1 \mathrm{serum} ; 154.78 \mathrm{mg} / 100 \mathrm{~g}$ liver $)$ and phospholipids $(1.01 \mathrm{mmol} / 1$ serum; $1788 \mathrm{mg} / 100 \mathrm{~g}$ liver) were decreased significantly $(P<0.05)$ in VCO-fed rats compared with those fed $\mathrm{CO}, \mathrm{OO}$ and SFO. Supplementation of VCO decreased the cholesterol levels $(22.72 \%$ decrease in serum and $51.25 \%$ decrease in liver) compared with rats fed CO. Similarly there was a $28.62 \%$ decrease in serum cholesterol levels and a $54.05 \%$ decrease in hepatic cholesterol levels in VCO-fed rats compared with rats fed OO. Decreased levels of TAG (15.38\% decrease in serum and $15.13 \%$ decrease in liver) and phospholipids ( $40.93 \%$ decrease in serum and $18.34 \%$ decrease in liver) were observed in VCO-fed rats compared with rats fed CO. A significant increase in TAG and phospholipids levels was

Table 3. Food intake and change in body weight (Mean values of six rats per group with their standard errors)

\begin{tabular}{llllll}
\hline & \multicolumn{2}{c}{$\begin{array}{c}\text { Food intake } \\
(\mathrm{g} / \mathrm{d})^{*}\end{array}$} & & \multicolumn{2}{c}{$\begin{array}{c}\text { Change in } \\
\text { body weight } \\
(\mathrm{g})^{*}\end{array}$} \\
\cline { 2 - 3 } \cline { 6 - 6 } Groups & Mean & SEM & & Mean & SEM \\
\hline Group I & 11.61 & 0.41 & & 65.55 & 2.43 \\
Group II & 12.12 & 0.49 & & 61.50 & 2.29 \\
Group III & 12.46 & 0.37 & & 66.25 & 2.63 \\
Group IV & 12.47 & 0.44 & & 66.75 & 2.67
\end{tabular}

Group I, 8\% copra oil-fed rats; group II, $8 \%$ virgin coconut oil-fed rats; group III, $8 \%$ olive oil-fed rats; group IV, $8 \%$ sunflower-seed oil-fed rats.

* Mean values were not significantly different.
Table 4. Cholesterol, TAG and phospholipid concentrations in serum and liver

(Mean values of six rats per group with their standard errors)

\begin{tabular}{|c|c|c|c|c|}
\hline & \multicolumn{2}{|c|}{ Serum $(\mathrm{mmol} / \mathrm{l})$} & \multicolumn{2}{|c|}{ Liver $(\mathrm{mg} / 100 \mathrm{~g})$} \\
\hline & Mean & SEM & Mean & SEM \\
\hline \multicolumn{5}{|l|}{ Cholesterol } \\
\hline Group I & $2 \cdot 42$ & 0.11 & 263.75 & 4.00 \\
\hline Group II & $1.87^{\star}$ & 0.08 & $128.57^{*}$ & 4.78 \\
\hline Group III & $2 \cdot 62 \dagger$ & 0.10 & $279.79 \dagger$ & 9.97 \\
\hline Group IV & $2 \cdot 18 \dagger$ & 0.08 & $265.36 \dagger$ & 9.85 \\
\hline \multicolumn{5}{|l|}{ TAG } \\
\hline Group I & $0 \cdot 13$ & 0.01 & $182 \cdot 38$ & $7 \cdot 14$ \\
\hline Group II & $0.11^{*}$ & 0.003 & $154 \cdot 78^{*}$ & 3.33 \\
\hline Group III & $0.15 \dagger$ & 0.01 & $286.33 \dagger$ & $10 \cdot 06$ \\
\hline Group IV & $0.14 \dagger$ & 0.01 & $215 \cdot 84 \dagger$ & 8.93 \\
\hline \multicolumn{5}{|c|}{ Phospholipids } \\
\hline Group I & 1.71 & 0.06 & $2195 \cdot 01$ & $81 \cdot 73$ \\
\hline Group II & $1.01^{*}$ & 0.04 & $1789.66^{*}$ & $66 \cdot 67$ \\
\hline Group III & $2.00 \dagger$ & 0.07 & $3307.72 \dagger$ & $123 \cdot 22$ \\
\hline Group IV & $1.72 \dagger$ & 0.06 & $2718.71 \dagger$ & 113.79 \\
\hline
\end{tabular}

Group I, $8 \%$ copra oil-fed rats; group II, $8 \%$ virgin coconut oil-fed rats; group III, $8 \%$ olive oil-fed rats; group IV, $8 \%$ sunflower-seed oil-fed rats.

${ }^{*}$ Mean value was significantly different from that of group I $(P<0.05)$.

$\dagger$ Mean value was significantly different from that of group II $(P<0.05)$.

observed in OO- (26.66\% increase in serum TAG and $49.50 \%$ increase in serum phospholipids) and SFO- (21.42\% increase in serum TAG and $41.28 \%$ increase in serum phospholipids) compared with VCO-fed rats.

\section{Effect on synthesis and oxidation of fatty acids}

Activities of enzymes involved in de novo fatty acid synthesis were assayed in the liver cytosolic fraction from rats fed the different test oils. Reduced rates of fatty acid synthesis were evident from the decreased activities of enzymes involved in fatty acid synthesis, namely ACC $(9.38 \mathrm{U} / \mathrm{mg}$ protein) and FAS (18.78 U/mg protein), in VCO-fed rats compared with rats fed $\mathrm{CO}, \mathrm{OO}$ and $\mathrm{SFO}$ (Fig. 1). However, the rates of mitochondrial $\beta$-oxidation $(0.305 \mathrm{U} / \mathrm{mg}$ protein) and peroxisomal $\beta$-oxidation ( $4.53 \mathrm{U} / \mathrm{mg}$ protein) were significantly $(P<0.05)$ increased in rats fed VCO compared with the other oil-fed rats (Table 5). Significant decreases in the activities of CPT I and ACO were observed in rats fed CO (13.07\% decrease in CPT I and 18.86\% decrease in ACO), OO (29.08\% decrease in CPT I and 30.78\% decrease in ACO) and SFO (18.30\% decrease in CPT I and $27.78 \%$ decrease in ACO) compared with VCO-fed rats (Fig. 2). The enzymes involved in mitochondrial $\beta$-oxidation, namely ACDH $(0.768 \mathrm{U} / \mathrm{mg}$ protein), enoyl CoA hydratase $(0 \cdot 304 \mathrm{U} / \mathrm{mg}$ protein $), \beta$-hydroxy acyl CoA dehydrogenase $(0.620 \mathrm{U} / \mathrm{mg}$ protein) and 3-ketoacyl CoA thiolase $(0.224 \mathrm{U} / \mathrm{mg}$ protein), were also increased significantly $(P<0.05)$ in rats fed VCO compared with the other oil-fed groups (Table 6). Significant decreases in the activities of ACDH (67.83\%), ECDH (47.03\%), $\beta$-hydroxy acyl CoA dehydrogenase (65.64\%) and 3-ketoacyl CoA thiolase (39.73\%) were observed in OO-fed rats compared with VCO-fed rats (Table 6). 


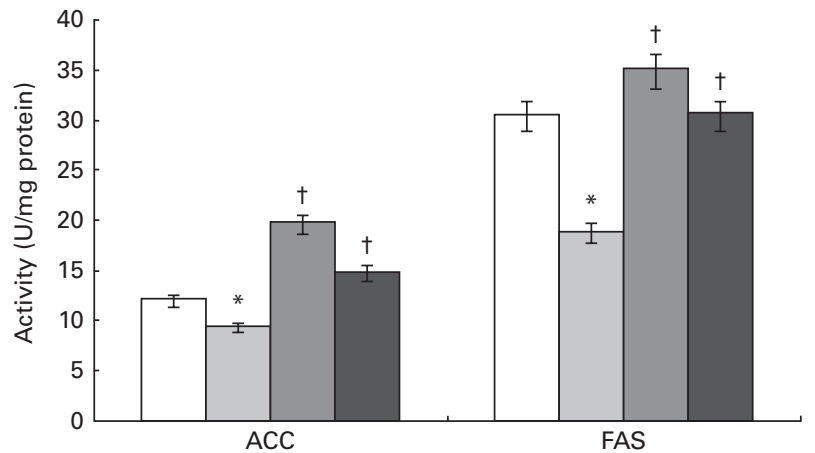

Fig. 1. Activity of acetyl $C o A$ carboxylase (ACC) and fatty acid synthase (FAS) in copra oil- ( $\square$ ), virgin coconut oil- ( $\square$ ), olive oil- ( $\square$ ) and sunflowerseed oil- $(\square)$ fed rats. Values are means of six rats per group, with their standard errors represented by vertical bars. ${ }^{*}$ Mean value was significantly different from that of group I $(P<0.05)$. † Mean value was significantly different from that of group II $(P<0.05)$.

\section{Effect on transcriptional regulation of fatty acid metabolism}

There was a down-regulation in the mRNA expression of FAS (the multi-enzyme complex involved in de novo fatty acid synthesis) and its transcription factor SREBP-1c in VCO-fed rats compared with the other oil-fed groups (Fig. 3). On the other hand, the mRNA expression of PPAR $\alpha$ and its target genes involved in fatty acid oxidation, namely CPT I and ACO, were up-regulated in VCO-fed rats compared with CO-, OO- and SFO-fed rats (Fig. 4)

\section{Discussion}

In the present study we compared the effects of VCO with CO, OO and SFO on the synthesis and oxidation of fatty acids and its effect on the molecular regulation of fatty acid metabolism in rats. There was no significant difference in food intake or change in body weight among the experimental groups. Supplementation of VCO decreased the concentration of lipids

Table 5. Effect of test oils on mitochondrial and peroxisomal $\beta$-oxidation

(Mean values of six rats per group with their standard errors)

\begin{tabular}{llllll}
\hline & \multicolumn{2}{c}{$\begin{array}{c}\text { Mitochondrial } \\
\beta \text {-oxidation (nmol } \\
\text { ferricyanide } \\
\text { reduced/mg }\end{array}$} & & & \multicolumn{2}{c}{$\begin{array}{c}\text { Peroxisomal } \\
\beta \text {-oxidation } \\
\text { (nmol NAD } \\
\text { protein per min) }\end{array}$} & & \multicolumn{2}{c}{$\begin{array}{c}\text { reduced/mg } \\
\text { protein per min) }\end{array}$} \\
\cline { 2 - 3 } Groups & Mean & SEM & & Mean & SEM \\
\hline Group I & 0.274 & 0.011 & & 3.76 & 0.154 \\
Group II & $0.305^{*}$ & 0.012 & & $4.53^{*}$ & 0.161 \\
Group III & $0.180 \dagger$ & 0.006 & & $3.62 \dagger$ & 0.125 \\
Group IV & $0.209 \dagger$ & 0.007 & & $2.69 \dagger$ & 0.098
\end{tabular}

Group I, $8 \%$ copra oil-fed rats; group II, $8 \%$ virgin coconut oil-fed rats; group III, $8 \%$ olive oil-fed rats; group IV, $8 \%$ sunflower-seed oil-fed rats.

* Mean value was significantly different from that of group I $(P<0.05)$.

† Mean value was significantly different from that of group II $(P<0.05)$.

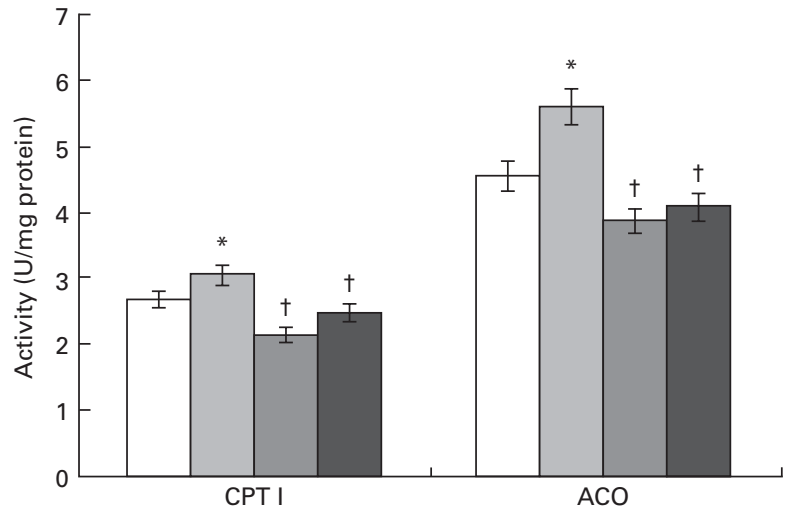

Fig. 2. Activity of carnitine palmitoyl transferase I (CPT I) and acyl CoA oxidase (ACO) in copra oil- $(\square)$, virgin coconut oil- ( $\square$ ), olive oil- $(\square$ ) and sunflower-seed oil- $(\square)$ fed rats. Values are means of six rats per group, with their standard errors represented by vertical bars. * Mean value was significantly different from that of group I $(P<0.05)$. $†$ Mean value was significantly different from that of group II $(P<0.05)$.

(cholesterol, TAG and phospholipids) in serum and liver when compared with CO-, OO- and SFO-fed rats. However, OO-fed rats showed an increased level of hepatic lipid accumulation compared with rats fed the other oils, which may be due to an increased lipogenesis and decreased catabolism of fats in OO-fed rats. There are reports that dietary fat influences the occurrences and prognosis of CHD, which is partially mediated by its effect on plasma lipids ${ }^{(40)}$.

Fatty acid biosynthesis in mammalian cells can be regulated in different ways. On a long-term basis, it is controlled by changes in the rate of synthesis of lipogenic enzymes ${ }^{(41)}$. As shown in Fig. 1, activities of enzymes involved in the de novo synthesis of fatty acids, namely ACC and FAS, were found to be decreased in VCO-fed rats compared with the other oil-fed rats. ACC catalyses the carboxylation of acetylCoA to produce malonyl-CoA for the biosynthesis of fatty acids $^{(42)}$ and FAS is the multi-enzyme complex needed for the de novo synthesis of fatty acids. There are reports of increased activities of lipogenic enzymes and hepatic lipid accumulation in OO-fed animals ${ }^{(43,44)}$. On the other hand, medium-chain TAG have a reductive effect on fat stores and a depressive effect on lipogenesis ${ }^{(45)}$. Fatty acid analysis of VCO extracted from fresh coconut kernel and CO extracted from dried copra revealed almost similar fatty acid content. Since there was no major difference in the fatty acid profiles among the two varieties of coconut oil, it is evident that the beneficial effect of VCO over CO is mainly due to the presence of unsaponifiable components, namely polyphenols and vitamin E. Studies revealed that apart from fatty acids, the unsaponifiable components present in dietary oils have a role in regulating hepatic lipid metabolism. Chemical analysis of the test oils has revealed that VCO by wet processing has increased polyphenolic contents $(84 \mathrm{mg} / 100 \mathrm{~g}$ oil), significantly higher than $\mathrm{CO}$ $(64.4 \mathrm{mg} / 100 \mathrm{~g}$ oil), OO $(75.63 \mathrm{mg} / 100 \mathrm{~g}$ oil) and SFO $(55.26 \mathrm{mg} / 100 \mathrm{~g} \text { oil })^{(20)}$. HPLC analysis of the phenolic fraction of VCO has revealed the presence of increased amounts of caffeic acid $(0.829 \mu \mathrm{g} / 100 \mathrm{~g}$ oil $), \quad p$-coumaric acid ( $5.43 \mu \mathrm{g} / 100 \mathrm{~g}$ oil), ferulic acid (9.91 $\mu \mathrm{g} / 100 \mathrm{~g}$ oil), (+)-catechin 
Table 6. Effect of test oils on mitochondrial $\beta$-oxidation enzymes

(Mean values of six rats per group with their standard errors)

\begin{tabular}{|c|c|c|c|c|c|c|c|c|}
\hline \multirow[b]{2}{*}{ Groups } & \multicolumn{2}{|c|}{$\begin{array}{c}\mathrm{ACDH}(\mathrm{U} / \mathrm{mg} \\
\text { protein) }\end{array}$} & \multicolumn{2}{|c|}{$\begin{array}{c}\mathrm{ECHD}(\mathrm{U} / \mathrm{mg} \\
\text { protein) }\end{array}$} & \multicolumn{2}{|c|}{$\begin{array}{l}\mathrm{HOAD}(\mathrm{U} / \mathrm{mg} \\
\text { protein) }\end{array}$} & \multicolumn{2}{|c|}{$\begin{array}{l}\mathrm{KAT}(\mathrm{U} / \mathrm{mg} \\
\text { protein) }\end{array}$} \\
\hline & Mean & SEM & Mean & SEM & Mean & SEM & Mean & SEM \\
\hline Group I & 0.626 & 0.021 & 0.204 & 0.006 & 0.384 & 0.045 & 0.180 & 0.006 \\
\hline Group II & $0.768^{*}$ & 0.027 & $0.304^{\star}$ & 0.010 & $0.620^{*}$ & 0.021 & $0.224^{*}$ & 0.006 \\
\hline Group III & $0.247 \dagger$ & 0.009 & $0.161 \dagger$ & 0.005 & $0.213 \dagger$ & 0.007 & $0.130 \dagger$ & 0.004 \\
\hline Group IV & $0.612 \dagger$ & 0.022 & $0.196 \dagger$ & 0.007 & $0.222 \dagger$ & 0.042 & $0.159 \dagger$ & 0.005 \\
\hline
\end{tabular}

ACDH, acyl CoA dehydrogenase; ECHD, enoyl CoA hydratase; HOAD, $\beta$-hydroxy acyl CoA dehydrogenase; KAT, 3-ketoacyl CoA thiolase; group I, $8 \%$ copra oil-fed rats; group II, $8 \%$ virgin coconut oil-fed rats; group III, $8 \%$ olive oil-fed rats; group IV, $8 \%$ sunflower-seed oil-fed rats.

${ }^{*}$ Mean value was significantly different from that of group I $(P<0.05)$.

$\dagger$ Mean value was significantly different from that of group II $(P<0.05)$.

hydrate $(0.983 \mu \mathrm{g} / 100 \mathrm{~g}$ oil) and syringic acid $(2.51 \mathrm{mg} / 100 \mathrm{~g}$ oil) compared with $\mathrm{CO}$, $\mathrm{OO}$ and $\mathrm{SFO}^{(22)}$; these observations are consistent with other studies ${ }^{(46)}$. In addition, the nonsaponifiable fraction of VCO contains appreciably higher amounts of antioxidants, namely vitamin $\mathrm{E}(33.12 \mu \mathrm{g} / 100 \mathrm{~g}$ oil) and $\beta$-carotene $(196 \mu \mathrm{g} / 100 \mathrm{~g} \text { oil })^{(20,22)}$. Increased amounts of these non-saponifible components present in VCO may partly be responsible for the decreased lipogenesis and lipid accumulation compared with other oils. Increased amounts of these bioactive non-saponifiable components may partly be responsible for the decreased lipogenesis and lipid accumulation compared with other oils.

There are reports that polyphenols can inhibit hepatic lipogenesis, promote hepatic lipid clearance ${ }^{(47)}$ and decrease serum and hepatic lipid accumulation ${ }^{(48,49)}$. Increased amounts of polyphenols present in VCO may decrease the lipid levels (cholesterol, TAG and phospholipids) compared with other oils. Some of the beneficial metabolic actions of polyphenols are mediated by their ability to activate sirtuin 1 (SIRT1) ${ }^{(50,51)}$ or AMP-activated protein kinase $(\mathrm{AMPK})^{(52)}$. SIRT1 is a NAD ${ }^{+}$dependent class III histone deacetylase ${ }^{(53)}$. Polyphenols stimulate hepatic SIRT1 activity and reduce lipid accumulation ${ }^{(52)}$; however, the underlying mechanisms remain unclear. There are reports that the polyphenols substantially prevent the impairment in phosphorylation of AMPK and its downstream target, ACC, elevation in the expression of FAS and lipid accumulation in human HepG2 hepatocytes ${ }^{(54)}$.

Furthermore, increased rates of mitochondrial and peroxisomal $\beta$-oxidation were observed in VCO-fed rats, which was evident from the increased activities of CPT I and ACO in VCO-fed rats compared with the other oil-fed rats. The OO-enriched diet showed a maximum decrease in the activity of CPT I, resulting in increased hepatic lipid accumulation in OO-fed rats. The present results are in agreement with previous reports ${ }^{(55)}$. Moreover, increased activities of mitochondrial $\beta$-oxidation enzymes, namely $\mathrm{ACDH}$, enoyl CoA hydratase, $\beta$-hydroxy acyl CoA dehydrogenase and 3-ketoacyl CoA thiolase, were observed in VCO-fed rats compared with the rats fed the other oils. There are reports that laurate present in coconut oil has a higher oxidation rate than oleate ${ }^{(56)}$ and the metabolites derived from long-chain fatty acids decrease activity of CPT I and the efficiency of ATP production $^{(57)}$. In addition, medium-chain TAG in coconut oil are transported predominantly in portal venous blood, extensively oxidised in the liver and less effectively incorporated into tissue lipids than other long-chain fatty acids $^{(58)}$. Thus lauric acid present in VCO may be partly responsible for the increased catabolism of fats and decreased accumulation of lipids.

In addition, an increased rate of peroxisomal $\beta$-oxidation was observed in VCO-fed rats, which was evident from the increased activity of ACO in peroxisomes compared with other oil-fed rats. There are reports that long-chain fatty acids $\left(>\mathrm{C}_{20}\right)$ require peroxisomal $\beta$-oxidation to shorten the chain length for further completion of oxidation in mitochondria. Thus both the substrate specificities and alterations in the activities of the $\beta$-oxidation enzymes may account for the lipid-lowering effects of dietary VCO. It has been reported that polyphenols can also increase peroxisomal $\beta$-oxidation and can suppress body fat accumulation ${ }^{(49)}$; thus, higher
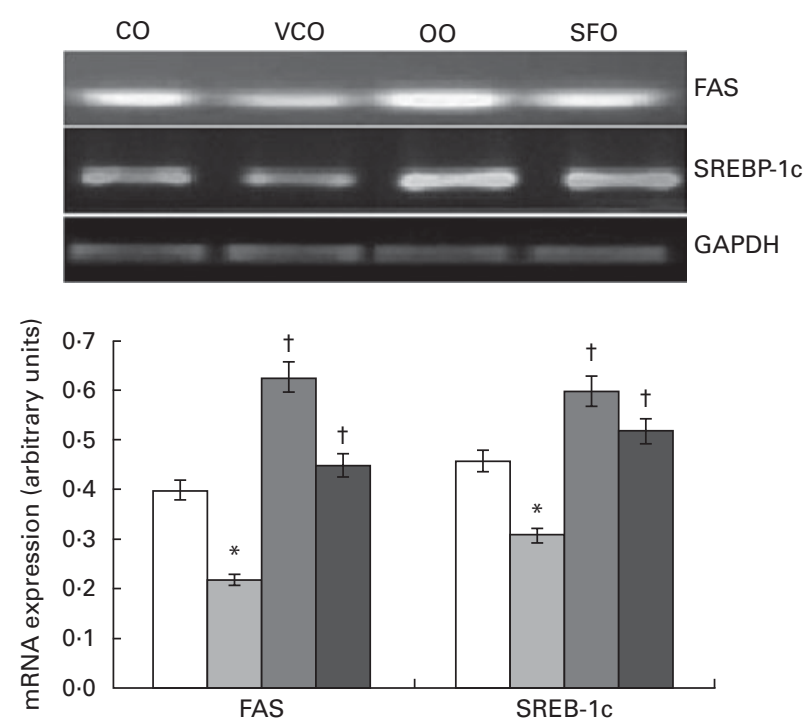

Fig. 3. mRNA expression of fatty acid synthase (FAS) and sterol regulatory element-binding protein-1c (SREBP-1c) in copra oil- (CO; $\square$ ), virgin coconut oil- (VCO; $\square$ ), olive oil- $(\mathrm{OO} ; \square)$ and sunflower-seed oil (SFO; $\square$ )-fed rats. Values are means of six rats per group, with their standard errors represented by vertical bars. * Mean value was significantly different from that of group I $(P<0.05)$. $†$ Mean value was significantly different from that of group II $(P<0.05)$. GAPDH, glyceraldehyde-3-phosphate dehydrogenase. 

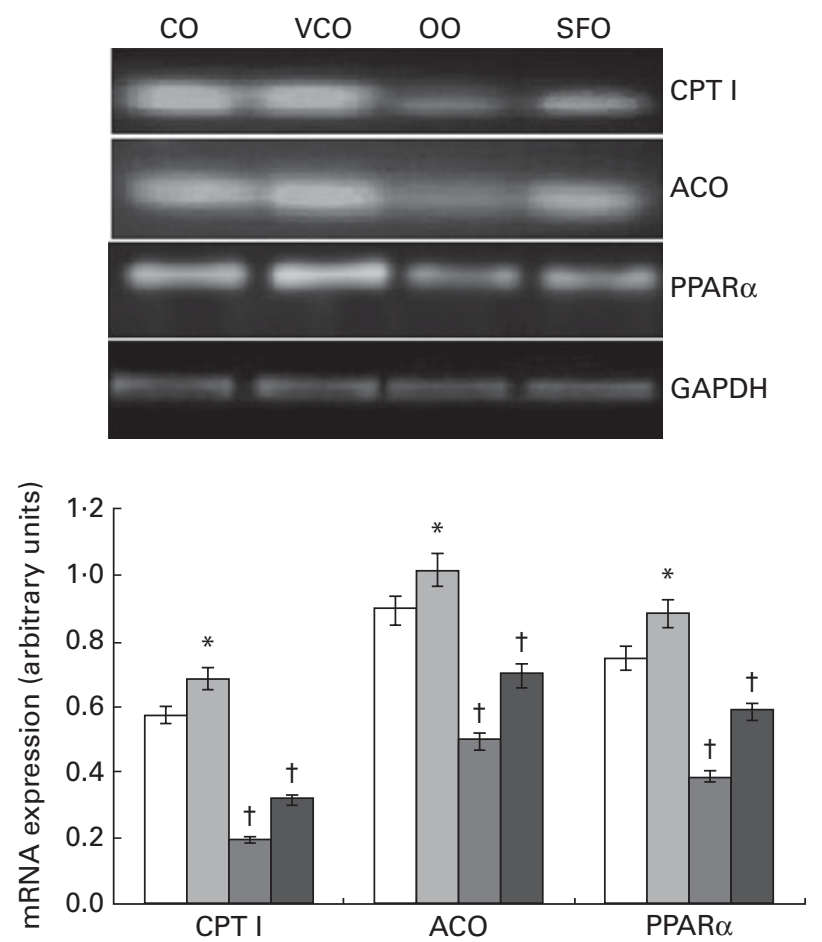

Fig. 4. mRNA expression of PPAR $\alpha$ and its target genes carnitine palmitoyl transferase I (CPT I) and acyl COA oxidase (ACO) involved in fatty acid oxidation in copra oil- $(\mathrm{CO} ; \square)$, virgin coconut oil- (VCO; $\square$ ), olive oil- $(\mathrm{OO} ; \square)$ and sunflower-seed oil (SFO; $\square$ )-fed rats. Values are means of six rats per group, with their standard errors represented by vertical bars. * Mean value was significantly different from that of group I $(P<0.05)$. $†$ Mean value was significantly different from that of group $\|(P<0.05)$. GAPDH, glyceraldehyde-3-phosphate dehydrogenase.

amounts of polyphenols in VCO may beneficially regulate fatty acid oxidation. The present study for the first time has evidence that dietary VCO increases the activities of both mitochondrial and peroxisomal enzymes involved in the fatty acid oxidation pathway.

The role of transcriptional regulation of fatty acid metabolism has been studied extensively. Reports indicate that dietary fatty acids suppress hepatic lipogenesis by reducing the transcription of genes coding for the participating enzymes ${ }^{(59,60)}$. Several lines of evidences have shown that down-regulation of SREBP-1c is a primary mechanism by which dietary fatty acids reduce hepatic lipogenesis. SREBP-1c stimulates the transcription of the enzymes that participate in the synthesis of fatty acids and $\mathrm{TAG}^{(8)}$; there was a down-regulation in the hepatic mRNA expression of FAS and its transcription factor SREBP-1c in VCO-fed rats compared with other oils. SREBP-1c is known to be regulated by the nutritional status of the individual and there are reports that polyphenols can reduce SREBP-1c expression $^{(61,62)}$. Since VCO contains higher amounts of polyphenols ${ }^{(17,20)}$, this may down-regulate the hepatic expression of SREBP-1c and hence reduce lipogenesis. A potential link between SIRT1 and SREBP-1c has also been suggested $^{(63)}$. Considerable evidence suggests that SIRT1 functions as a master metabolic regulator by either directly modifying histones or by indirectly regulating the activities of several transcriptional regulators ${ }^{(63,64)}$. There are reports that polyphenols increase SIRT1 deacetylase activity ${ }^{(54)}$, deacetylation of SREBP-1c by SIRT1 inhibits SREBP-1c activity by decreasing its stability and its association with its lipogenic target gene promoters ${ }^{(63,65)}$

Moreover, both mitochondrial and peroxisomal $\beta$-oxidation systems are under the transcriptional regulation of PPAR $\alpha$, which is the nuclear receptor activated by natural ligands such as fatty acids ${ }^{(10)}$. There are reports that medium-chain fatty acids are the natural PPAR ligands ${ }^{(66)}$ and supplementation of coconut oil up-regulates the mRNA expression of PPAR $\alpha^{(67)}$. Moreover, polyphenols are reported to be the natural PPAR $\alpha$ activators $^{(49,68)}$. PPAR $\alpha$ activation up-regulates fatty acid oxidation-related genes such as ACO, CPT I, etc. ${ }^{(69)}$ and suppresses postprandial lipidaemia and lipid accumulation through the enhancement of fatty acid oxidation ${ }^{(70)}$. An up-regulation in the mRNA expression of PPAR $\alpha$ and its target genes involved in fatty acid oxidation was observed in VCO-fed rats compared with the other oil-fed rats; these results were correlated with the increased activities of enzymes involved in mitochondrial and peroxisomal $\beta$-oxidation in VCO-fed rats. Thus, from the present results it is clear that supplementation of VCO regulates fatty acid oxidation partly via PPAR $\alpha$-dependent pathways.

In conclusion, dietary VCO beneficially modulates lipid levels and fatty acid metabolism by transcriptional regulation of the enzymes involved in the synthesis and oxidation of fatty acids.

\section{Acknowledgements}

Financial assistance in the form of a research fellowship from the University of Kerala (grant number 5825/2009) to S. A. is gratefully acknowledged; the University of Kerala had no role in the design, analysis or writing of this article.

S. A. designed and performed the experiment, analysed the data and prepared the manuscript. T. R. was responsible for the very concept and design of the study, interpretation of the data and formulation of research questions. All authors read and approved the final manuscript.

The authors declare that they have no conflicts of interest.

\section{References}

1. Hyson D, Rutledge JC \& Berglund L (2003) Postprandial lipemia and cardiovascular disease. Curr Atheroscler Rep 5 , 437-444.

2. Kłosiewicz-Latoszek L, Pachocka L, Górska K, et al. (1997) Risk factors for coronary heart disease in 1002 patients with hyperlipidemia. Pol Arch Med Wewn 97, 442-449.

3. Donnelly KL, Smith CI, Schwarzenberg SJ, et al. (2005) Sources of fatty acids stored in liver and secreted via lipoproteins in patients with nonalcoholic fatty liver disease. J Clin Invest 115, 1343-1351.

4. Iritani N, Fukuda H \& Tada K (1996) Nutritional regulation of lipogenic enzyme gene expression in rat epididymal adipose tissue. J Biochem 120, 242-248.

5. Clarke SD (2004) The multi-dimensional regulation of gene expression by fatty acids: polyunsaturated fats as nutrient sensors. Curr Opin Lipidol 15, 13-18.

6. Jump DB, Botolin D, Wang Y, et al. (2005) Fatty acid regulation of hepatic gene transcription. J Nutr 135, 2503-2506. 
7. Guillou H, Martin PG \& Pineau T (2008) Transcriptional regulation of hepatic fatty acid metabolism. Subcell Biochem 49, 3-47.

8. Horton JD, Goldstein JL \& Brown MS (2002) SREBPs: activators of the complete program of cholesterol and fatty acid synthesis in liver. J Clin Invest 109, 1125-1131.

9. Latruffe $\mathrm{N}$, Cherkaoui Malki M, Nicolas-Frances $\mathrm{V}$, et al. (2000) Regulation of the peroxisomal $\beta$-oxidationdependent pathway by peroxisome proliferator activated receptor $\alpha$ and kinases. Biochem Pharmacol 15, 1027-1032.

10. Reddy JK \& Hashimoto T (2001) Peroxisomal $\beta$-oxidation and peroxisome proliferator-activated receptor $\alpha$ : an adaptive metabolic system. Annu Rev Nutr 21, 193-230.

11. Hashimotto T, Cook WS, Qi C, et al. (2000) Defect in peroxisome proliferator activator receptor $\alpha$ inducible fatty acid oxidation determines the severity of hepatic steatosis. $J$ Biol Chem 275, 28918-28928.

12. Kelley DS, Nelson GJ \& Hunt JE (1986) Effect of prior nutritional status on the activity of lipogenic enzymes in primary monolayer cultures of rat hepatocytes. Biochem J 235, 87-90.

13. Leveille GA (1967) Influence of dietary fat level on the enzymatic and lipogenic adaptations in adipose tissue of meal-fed rats. J Nutr 91, 267-274.

14. Mickelsen O, Takahashi S \& Craig C (1955) Experimental obesity. 1. Production of obesity in rats by feeding high-fat diets. J Nutr 57, 541-554.

15. Nevin KG \& Rajamohan T (2006) Virgin coconut oil diet increases the antioxidant status in rats. Food Chem 99, $260-266$.

16. DeLany JP, Windhauser MM, Champagne CM, et al. (2000) Differential oxidation of individual dietary fatty acids in humans. Am J Clin Nutr 72, 905-911.

17. Nevin KG \& Rajamohan T (2004) Beneficial effects of virgin coconut oil on lipid parameters and in vitro LDL oxidation. Clin Biochem 37, 830-835.

18. Nevin KG \& Rajamohan T (2009) Wet and dry extraction of coconut oil: impact on lipid metabolic and antioxidant status in cholesterol co administered rats. Can J Physiol Pharmacol 87, 610-616.

19. Nevin KG \& Rajamohan $T$ (2008) Influence of virgin coconut oil on blood coagulation factors, lipid levels and LDL oxidation in cholesterol fed Sprague-Dawley rats. e-SPEN. Eur e-J Clin Nutr Metabol 3, e1-e8.

20. Arunima S \& Rajamohan T (2012) Virgin coconut oil improves hepatic lipid metabolism in rats compared with copra oil, olive oil and sunflower oil. Indian J Exp Biol 50, 802-809.

21. Lombardo YB, Chicco A, D'Alessandro ME, et al. (1996) Dietary fish oil normalize dyslipidemia and glucose intolerance with unchanged insulin levels in rats fed a high sucrose diet. Biochim Biophys Acta 1299, 175-182.

22. Arunima S \& Rajamohan T (2013) Effect of virgin coconut oil enriched diet on the antioxidant status and paraoxonase 1 activity in ameliorating the oxidative stress in rats - a comparative study. Food Funct 4, 1402-1409.

23. Folch J, Lees N \& Sloane Stanley GH (1957) A simple method for the isolation and purification of total lipides from animal tissues. J Biol Chem 226, 497-509.

24. Carr JJ \& Drekter IJ (1956) Simplified rapid technique for the extraction and determination of serum cholesterol without saponification. Clin Chem 2, 353-368.

25. Van Handel E \& Zilversmit DB (1957) Micromethod for the direct determination of serum triglycerides. J Lab Clin Med 50, 152-157.

26. Zilversmit DB \& Davis AK (1950) Microdetermination of plasma phospholipids by trichloroacetic acid precipitation. J Lab Clin Med 35, 155-160.
27. Tyler DD \& Gonze J (1967) The preparation of heart mitochondria from laboratory animals. Methods Enzymol 10 75-77.

28. Grum DE, Hansen LR \& Drackley JK (1994) Peroxisomal $\beta$-oxidation of fatty acids in bovine and rat liver. Comp Biochem Physiol 109, 281-292.

29. Lowry OH, Rosebrough NJ, Farr AL, et al. (1951) Protein measurement with the folin phenol reagent. $J$ Biol Chem 193, 265-275.

30. Osmundsen H (1981) Spectophotometric procedure for measuring mitochondrial $\beta$-oxidation. Methods Enzymol 72, 306-314.

31. Ide T, Watanabe M, Sugano M, et al. (1987) Activities of liver mitochondrial and peroxisomal fatty acid oxidation enzymes in rats fed trans fat. Lipids 22, 6-10.

32. Dommes V \& Kunau WH (1976) A convenient assay for acyl CoA dehydrogenase. Anal Biochem 71, 571-578.

33. Osumi T \& Hashimoto T (1979) Subcellular distribution of the fatty acid-CoA $\beta$-oxidation system and their induction by di (2-ethylexyl) phthalate in rat liver. $J$ Biochem $\mathbf{8 5}$, 131-139.

34. Osumi $\mathrm{T}$ \& Hashimoto $\mathrm{T}$ (1979) Occurrence of two 3-hydroxyacyl-CoA dehydrogenases in rat liver. Biochim Biophys Acta 574, 258-267.

35. Lynen F \& Ochoa S (1953) Enzymes of fatty acid metabolism. Biochim Biophys Acta 12, 299-314.

36. Shimizu S, Yasui K, Tani Y, et al. (1979) Acyl-CoA oxidase from Candida tropicalis. Biochem Biophys Res Commun 91, 108-113.

37. Inoue H \& Lowenstein JM (1975) Acetyl CoA carboxylase from rat liver. Methods Enzymol 35, 3-11.

38. Kim IC, Neudahl G \& Deal WC Jr (1981) Fatty acid synthase from pig liver. Methods Enzymol 71, 79-85.

39. Chomczynski P \& Mackey K (1995) Substitution of chloroform by bromochloropropane in the single-step method of RNA isolation. Anal Biochem 225, 163-164.

40. Hu FB, Manson JE \& Willett WC (2001) Types of dietary fat and risk of coronary heart disease: a critical review. $J \mathrm{Am}$ Coll Nutr 20, 5-19.

41. Gibson DM, Lyons RT, Scott DF, et al. (1972) Synthesis and degradation of the lipogenic enzymes of rat liver. $A d v$ Enzyme Regul 10, 187-204.

42. Tong L (2005) Acetyl-coenzyme A carboxylase: crucial metabolic enzyme and attractive target for drug discovery. Cell Mol Life Sci 62, 1784-1803.

43. Portillo MP, Chavari M, Duran D, et al. (2001) Differential effects of diets that provide different lipid sources on hepatic lipogenic enzyme activities in rats under ad libitum or restricted feeding. Nutrition 17, 463-471.

44. Takeuchi H, Nakamoto T, Mori Y, et al. (2001) Comparative effects of dietary fat types on hepatic enzyme activities related to the synthesis and oxidation of fatty acid and to lipogenesis in rats. Biosci Biotechnol Biochem $\mathbf{6 5}$, $1748-1754$.

45. Lavau MM \& Hashim SA (1978) Effect of medium chain triglyceride on lipogenesis and body fat in the rat. $J$ Nutr 108, 613-620.

46. Seneviratne KN \& Dissanayake MS (2008) Variation of phenolic content in coconut oil extracted by two conventional methods. Int J Food Sci Nutr 43, 597-602.

47. Yang MY, Peng CH, Chan KC, et al. (2010) The hypolipidemic effect of Hibiscus sabdariffa polyphenols via inhibiting lipogenesis and promoting hepatic lipid clearance. J Agric Food Chem 27, 850-859.

48. Zern TL, West KL \& Fernandez ML (2003) Grape polyphenols decrease plasma triglycerides and cholesterol accumulation 
in the aorta of ovariectomized guinea pigs. J Nutr 133 2268-2272.

49. Fukuchi Y, Hiramitsu M, Okada M, et al. (2008) Lemon polyphenols suppress diet-induced obesity by up-regulation of mRNA levels of the enzymes involved in $\beta$-oxidation in mouse white adipose tissue. J Clin Biochem Nutr 43, 201-209.

50. Lagouge M, Argmann C, Gerhart-Hines Z, et al. (2006) Resveratrol improves mitochondrial function and protects against metabolic disease by activating SIRT1 and PGC- $1 \alpha$. Cell 127, 1109-1122.

51. Baur JA, Pearson KJ, Price NL, et al. (2006) Resveratrol improves health and survival of mice on a high-calorie diet. Nature 444, 337-342.

52. Zang M, Xu S, Maitland-Toolan KA, et al. (2006) Polyphenols stimulate AMP-activated protein kinase, lower lipids, and inhibit accelerated atherosclerosis in diabetic LDL receptordeficient mice. Diabetes 55, 2180-2191.

53. Haigis MC \& Guarente LP (2006) Mammalian sirtuins: emerging roles in physiology, aging, and calorie restriction. Genes Dev 20, 2913-2921.

54. Hou X, Xu S, Maitland-Toolan KA, et al. (2008) SIRT1 regulates hepatocyte lipid metabolism through activating AMP-activated protein kinase. J Biol Chem 283, 20015-20026.

55. Ferramosca A, Savy V \& Zara V (2008) Olive oil increases the hepatic triacylglycerol content in mice by a distinct influence on the synthesis and oxidation of fatty acids. Biosci Biotechnol Biochem 721, 62-69.

56. Piot C, Hocquette JF, Veerkamp JH, et al. (1999) Effect of dietary coconut oil on fatty acid oxidation capacity of the liver, the heart and skeletal muscles in preruminant calf. Br J Nutr 82, 299-308.

57. Hocquette JF \& Bacchart DS (1999) Intestinal absorption, blood transport and hepatic and muscle metabolism of fatty acids in preruminant and ruminant animals. Reprod Nutr Dev 39, 27-48.

58. Scheig R (1968) Hepatic metabolism of medium chain fatty acids. In Medium Chain Triglycerides, pp. 39-49 [JR Senior, TB Van Itallie and NJ Greenberger, editors]. Philadelphia, PA: University of Pennsylvania Press.

59. Jump DB, Thelen A \& Mater M (1999) Dietary polyunsaturated fatty acids and hepatic gene expression. Lipids $\mathbf{3 4}$, S209-S212.
60. Clarke SD (2000) Polyunsaturated fatty acid regulation of gene transcription: a mechanism to improve energy balance and insulin resistance. Br J Nutr 83, S59-S66.

61. Mukai Y, Sun Y \& Sato S (2013) Azuki bean polyphenols intake during lactation upregulate AMPK in male rat offspring exposed to fetal malnutrition. Nutrition 29, 291-297.

62. Murase T, Misawa K, Minegishi Y, et al. (2011) Coffee polyphenols suppress diet-induced body fat accumulation by downregulating SREBP-1C and related molecules in C57BL/6J mice. Am J Physiol Endocrinol Metab 300, E122-E133.

63. Rodgers JT \& Puigserver P (2007) Fasting-dependent glucose and lipid metabolic response through hepatic sirtuin 1. Proc Natl Acad Sci U S A 104, 12861-12866.

64. Rodgers JT, Lerin C, Haas W, et al. (2005) Nutrient control of glucose homeostasis through a complex of PGC-1 $\alpha$ and SIRT1. Nature 434, 113-118

65. Ponugoti B, Kim DH, Xiao Z, et al. (2010) SIRT1 deacetylates and inhibits SREBP-1C activity in regulation of hepatic lipid metabolism. J Biol Chem 285, 33959-33970.

66. Marcelo VL, Alessandro SN, Steven D, et al. (2012) Medium chain fatty acids are selective peroxisome proliferator activated receptor (PPAR) $\gamma$ activators and pan-PPAR partial agonists. PLOS ONE 7, E36297.

67. Bonilla S, Redonnet A, Noël-Suberville C, et al. (2000) High-fat diets affect the expression of nuclear retinoic acid receptor in rat liver. Br J Nutr 83, 665-671.

68. Kaul D, Sikand K \& Shukla AR (2004) Effect of green tea polyphenols on the genes with atherosclerotic potential. Phytother Res 18, 177-179.

69. Pineda Torra IP, Gervois \& Staels B (1999) Peroxisome proliferator activated receptor $\alpha$ in metabolic disease, inflammation, atherosclerosis and aging. Curr Opin Lipidol 10, 151-159.

70. Kimura R, Takahashi N, Murota K, et al. (2011) Activation of peroxisome proliferator-activated receptor- $\alpha$ (PPAR $\alpha$ ) suppresses postprandial lipidemia through fatty acid oxidation in enterocytes. Biochem Biophys Res Commun $\mathbf{4 1 0}$, $1-6$.

71. Hubbell RB, Mendel LB \& Wakeman AJ (1937) A new salt mixture for use in experimental diets. J Nutr 14, $273-285$. 